\title{
EFFECT OF ULTRAVIOLET RADIATION (UVR) ON THE TROPICAL MICROALGA Chlorella vulgaris
}

\author{
${ }^{1}$ Wong C.Y.*, ${ }^{2}$ Teoh M.L., ${ }^{3}$ Phang S.M. and ${ }^{4}$ Chu W.L.
}

${ }^{1}$ National Antarctic Research Centre, University of Malaya, 50603 Kuala Lumpur, Malaysia; ${ }^{2,3}$ Institute of Ocean and Earth Sciences, University of Malaya 50603 Kuala Lumpur, Malaysia; ${ }^{4}$ International Medical University, Plaza Komanwel, Bukit Jalil 57000, Kuala Lumpur, Malaysia.

*chiew_yen@um.edu.my (corresponding author)

Received on 10th February 2011, accepted in revised form 23rd March 2011.

ABSTRACT The effect of ultraviolet radiation (UVR) on the growth, lipid content and fatty acid profile of the tropical microalga Chlorella vulgaris UMACC 001 was investigated under laboratory and natural UVR conditions. The Chlorella was exposed to 10 days of PAR+UVA+UVB $\left(1.17 \mathrm{Wm}^{-2}\right)$, PAR+UVA $\left(8.54 \mathrm{Wm}^{-2}\right)$ and PAR alone $\left(42 \mu \mathrm{molm}^{-2} \mathrm{~s}^{-1}\right)$ in the laboratory study. The natural UVR study was carried out by exposing the cultures to the natural environment on the roof-top of the Institute of Graduate Studies Building, University of Malaya for 54 hours. The average levels of UVA radiation, UVB radiation and PAR irradiance over the exposure period ranged from 3.66 to $27.95 \mathrm{Wm}^{-2}, 1.61$ to $16.50 \mathrm{Wm}^{-}$ ${ }^{2}$ and 282 to $1480 \mu \mathrm{mol} \mathrm{m} \mathrm{m}^{-2} \mathrm{~s}^{-1}$, respectively. UVA radiation did not affect the growth of Chlorella vulgaris UMACC 001 in both the laboratory and natural UVR studies. In contrast, growth was adversely affected by UVB radiation in the laboratory study. UVB radiation is known to decrease the stability of D1 protein (the herbicide binding protein of chloroplasts) of the photosystem II reaction centre (PSII), affect rubisco activity, pigment composition as well as generate superoxide dismutase, all of which would reduce photosynthesis and growth. No significant difference was observed in the lipid content of the cultures exposed to UVR compared to PAR alone in both laboratory and roof-top (natural UVR) cultures. Chlorella vulgaris UMACC 001 exhibited different response in fatty acid profiles under laboratory condition compared to roof-top (natural UVR) cultures. In the laboratory condition, more saturated fatty acids (SFA) were produced in the cultures exposed to laboratory-produced UVB radiation compared to PAR alone, while more polyunsaturated fatty acids (PUFAs) were produced in the cultures exposed to natural UVB radiation compared to PAR alone.

Abstrak Kesan radiasi ultraungu ke atas pertumbuhan, kandungan lemak dan profil asid lemak bagi mikroalga tropika Chlorella vulgaris UMACC 001 telah disiasat dalam keadaan makmal dan semulajadi. Chlorella tersebut didedah kepada PAR+UVA+UVB $\left(1.17 \mathrm{Wm}^{-2}\right)$, PAR+UVA $\left(8.54 \mathrm{Wm}^{-2}\right)$ dan PAR persendirian $\left(42 \mathrm{~mol} \mathrm{~m}^{-2} \mathrm{~s}^{-1}\right)$ selama 10 hari dalam kajian makmal. Kajian semulajadi radiasi ultraungu dijalankan dengan mendedahkan kultur tersebut kepada persekitaran semulajadi di atas bumbung bangunan Institut Penggajian Pascasiswazah, Universiti Malaya selama 54 jam. Paras purata radiasi UVA, UVB dan PAR dalam tempoh pendedahan radiasi ultraungu semulajadi adalah 3.66 hingga $27.95 \mathrm{Wm}^{-2}, 1.61$ hingga 16.50 $\mathrm{Wm}^{-2}$ dan 282 hingga $1480 \mu \mathrm{mol} \mathrm{m} \mathrm{m}^{-2} \mathrm{~s}^{-1}$, masing-masing. Tiada kesan radiasi UVA ke atas tumbesaran Chlorella vulgaris UMACC 001 dalam kedua-dua eksperimen makmal dan semulajadi. Sebaliknya tumbesaran mikroalga tersebut menurun dengan ketara apabila didedahkan kepada radiasi UVB di dalam makmal. Diketahui bahawa radiasi UVB mengurangkan kestabilan protein D1 dalam fotosistem II (PSII), mempengaruhi aktiviti rubisco, komposisi pigment dan menghasilkan radikal superoxide yang mana semua akan mengurangkan fotosintesis dan tumbesaran. Tiada perbezaan ketara diperhatikan dalam kandungan lemak bagi kultur yang didedahkan kepada radiasi ultraungu berbanding dengan PAR persendirian dalam kedua-dua kajian makmal dan semulajadi. Chlorella vulgaris UMACC 001 menunjukkan tindak balas yang berbeza dalam profil asid lemak apabila kultur tersebut didedahkan kepada radiasi ultraungu dalam keadaan makmal dan semulajadi. Dalam keadaan makmal, lebih banyak asid lemak tepu (SFA) dihasilkan dalam kultur yang didedahkan kepada radiasi UVB berbanding dengan PAR persendirian, tetapi lebih banyak asid lemak poli tidak tepu (PUFAs) dihasilkan dalam kultur yang didedahkan kepada radiasi ultraungu-B semulajadi berbanding dengan PAR persendirian di atas bumbung (radiasi ultraungu semulajadi).

(Keywords: ultraviolet radiation, tropics, microalgae, Chlorella vulgaris, growth, fatty acids, lipids, algae biotechnology) 


\section{INTRODUCTION}

One of the seriously debated environmental issues among scientists is the depletion of the ozone layer which causes an increase of UVB radiation reaching the Earth's surface. The ozone layer is vital to organisms on Earth as it protects organisms from direct ultraviolet radiation (UVR). The amount of ozone that shields the Earth's surface from UVR has been reported to have decreased by an average of 3\% globally over the last decade and the ozone hole increased steadily $[1,2]$. Ozone depletion is expected to increase and spread over a broader range of altitudes and latitudes throughout most of the current century [3]. It is predicted to increase in severity and duration in the coming decades and continue until at least 2020 [4,5] although the growth in CFC levels is decreasing in response to the Montreal Protocol [6]. The most severe depletion is predicted to occur during 2010 - 2019 [5,7].

UVA (320-400nm) and UVB (280-320) radiation are the two major forms of UVR well known to have deleterious effects on many organisms on the Earth. The increase of UVR has been reported to affect growth, photosynthesis, biochemical composition, nutrient uptake, reproduction and many other physiological processes as well as causes damage to DNA of microalgae which populate terrestrial and aquatic ecosystems [8-13]. Furthermore, UVR may cause nonspecific damage by generating highly reactive oxidants such as singlet $\mathrm{O}_{2}$, superoxide $\left(\mathrm{O}_{2}^{-}\right)$, hydroxyl radicals and hydrogen peroxide [14]. These highly reactive oxidants may lead to pigment bleaching and the destruction of the cellular components [15]. The nutritional value of algae may be affected by UVR stress as shown by the decreased levels of omega-3 fatty acids in Pavlova lutheri and Isochrysis galbana [16] and diatoms $[10,11]$. There are increasing concerns about the deleterious effects of UVR on algae because any changes to the size and composition of algae communities will directly affect food production from the marine ecosystem $[17,18]$.

Studies showed that UVB radiation induced impairment of photosynthesis by decreasing the stability of D1 protein of the PSII reaction centre, triggering increased degradation of this protein $[19,20]$, and contribute to a lower photosynthetic efficiency [21,22]. The net loss of D1 pools due to increased UVB radiation has been studied in temperate and tropical natural phytoplankton assemblages [23]. Besides that, UVR may affect rubisco activity [24], pigment composition [25], carbon fixation [26], maximum quantum yield $\left(\mathrm{F}_{\mathrm{v}} / \mathrm{F}_{\mathrm{m}}\right)$ and also the electron transport rate (ERTmax) [27-30] or induce structural alterations of thylakoid membranes [31] as well as reduced expression of genes involved in photosynthesis [32] thus resulting in the inhibition of photosynthesis and growth in algae. The PSII of the cold ocean diatoms Pseudonitzcshia seriata and Nitzchia sp. was affected when exposed to UVB radiation, with the decrease of $\mathrm{F}_{\mathrm{v}} / \mathrm{F}_{\mathrm{m}}$ ratio by $27 \%$ compared to non-UVB exposed cultures [29]. A 10 to $25 \%$ loss in photosynthetic activity was observed in Isochrysis galbana and Dicrateria inornata grown under UVB radiation [33].

Microalgae have developed several strategies to cope with potentially harmful ambient UVR. One defense strategy is by avoidance, through migration to deeper water columns [34]. Another form of protection is achieved by synthesising or accumulating a series of photoprotective compounds such as mycosporine-like amino acids (MAAs) or antioxidant compounds that directly or indirectly absorb the energy of the solar radiation $[14,35,36]$. Fatty acids especially saturated fatty acid (SFA) could be an adaptation strategy in stress response because this fatty acid actually serves as an energy source for stress adaptation. It was found that the percentage of SFA in microalgae from Antarctic, tropical and temperate regions increased in response to UVB stress $[10,11]$.

Microalgae are important primary producers which dominate terrestrial and aquatic ecosystems. They form the basis of the food web and account for up to $60 \%$ of the total global oxygen production and about $50 \%$ of the global carbon dioxide fixation $[33,37]$. The microalga Chlorella is one of the best-studied phototrophic eukaryotes. Chlorella is a small coccoid green alga with cosmopolitan occurrence. In recent years, the use of Chlorella in life science research has received increasing attention. This chlorophyte has potential applications as dietary supplements in human nutrition which are able to provide additional physiological and pharmacological benefits for human health [38]. Chlorella strains are also being used for a variety 
of applications in biotechnology such as production of antioxidative compounds [39], waste water treatment [40] and as feedstock for biofuel production [41].

The aim of the present study is to compare the effect of UVR on the growth, lipid content and fatty acid profiles of tropical Chlorella vulgaris UMACC 001 grown under laboratory and field conditions. The findings will be useful in providing reference data for future assessment of possible changes in environmental conditions especially increasing levels of UVR on tropical microalgae.

\section{MATERIAL AND METHODS}

\section{Algae culture}

Chlorella vulgaris UMACC 001 used in the present study was obtained from the University of Malaya Algae Culture Collection (UMACC) [42] (Figure 1). It was isolated from a pond at the experimental farm of the University of Malaya. The cultures were grown in Bold's Basal Medium [BBM; 43] and maintained in a controlled-environment incubator at $28^{\circ} \mathrm{C}$, with cool white fluorescent lamps $\left(42 \mu \mathrm{mol} \mathrm{m} \mathrm{m}^{-2}\right)$ on a 12:12h light-dark cycle.

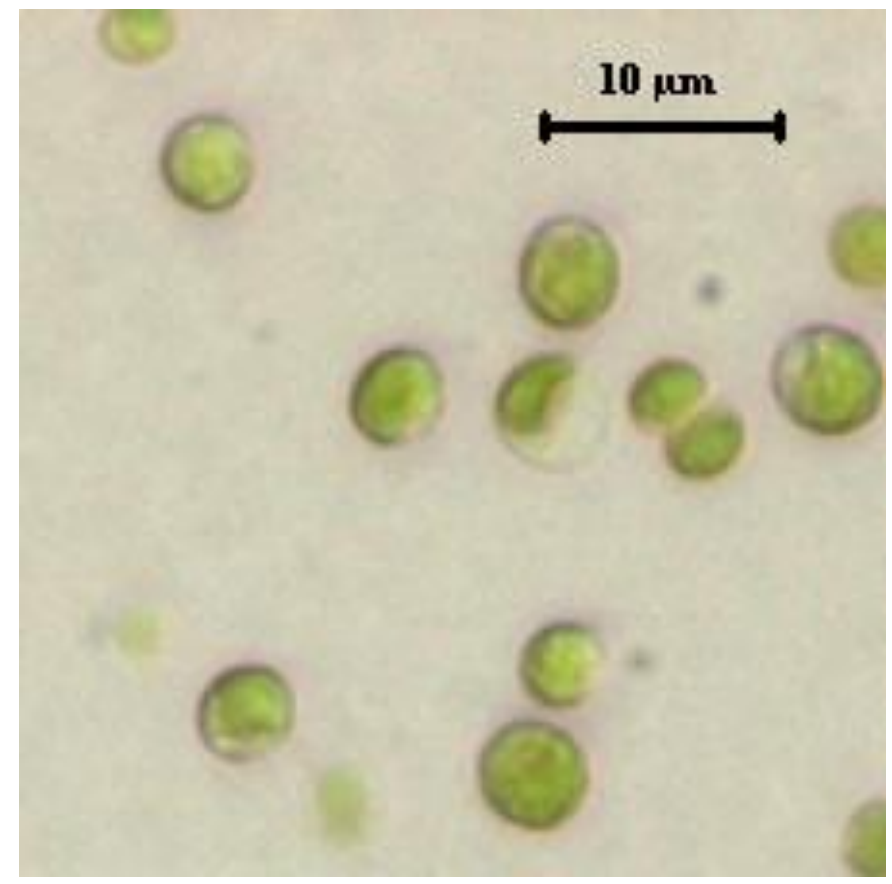

Figure 1: Chlorella vulgaris UMACC 001

\section{Experimental design}

For the laboratory study, the culture was exposed to three light treatments: $\mathrm{PAR}+\mathrm{UVA}+\mathrm{UVB}$, PAR+UVA and PAR alone in the incubator set at $28^{\circ} \mathrm{C}$ with a $12 \mathrm{~h}: 12 \mathrm{~h}$ light dark cycle for 10 days. The cultures were irradiated with a combination of three types of lamps: two tubes of day light fluorescent lamps providing $42 \mu \mathrm{mol}$ $\mathrm{m}^{-2} \mathrm{~s}^{-1}$ of photosynthetically active radiation (PAR), one tube of UVB lamp (38W, Phillip) providing irradiance of $1.17 \mathrm{Wm}^{-2}$ and two tubes of UVA lamps (18W, Phillip) providing irradiance of $8.54 \mathrm{Wm}^{-2}$. For the natural UVR study, the cultures were exposed to the natural environment on the roof-top of the Institute of Graduate Studies Building, University of Malaya for 54h. An inoculum size of $20 \%$ standardized at an optical density at $620 \mathrm{~nm}\left(\mathrm{OD}_{620 \mathrm{~nm}}\right)$ of 0.2 from exponential phase cultures was used. The cultures were grown in triplicate in beakers and Whirl-Pack ${ }^{\mathrm{R}}$ bags for laboratory and field study, respectively. Various cut-off filters were used to obtain the different UVR treatments. For the PAR alone, the culture was covered with polycarbonate sheet to eliminate UVA and UVB radiation. To obtain the PAR+UVA treatment, Mylar sheet was used to cut off the UVB radiation. The culture receiving PAR+UVA+UVB was covered with WhirlPack $^{\mathrm{R}}$ bag to allow light spectrum above $280 \mathrm{~nm}$ to pass through.

\section{Meteorological Data}

Selected meteorological parameters were 
monitored during the natural UVR experiment on the roof-top of the Institute of Graduate Studies, University of Malaya. Temperature and UVR were measured using thermometer and UV radiometer, respectively. The PAR was measured as irradiance using Pan Lux meter and was converted to mol m $\mathrm{m}^{-2}$ following equation below [44]:

$$
10,000 \mathrm{Lux}=0.1345 \mathrm{~mol} \mathrm{~m}^{-2} \mathrm{~s}^{-1}
$$

Growth studies

Growth was monitored by measuring the $\mathrm{OD}_{620 \mathrm{~nm}}$ and determining the chlorophyll $a$ concentration. Chlorophyll $a$ was determined by spectrophotometry after extraction of the filtered samples (glass-fibre filters, $0.45 \mu \mathrm{m}$ ) in acetone [45]. Specific growth rate $(\mu)\left(d^{-1}\right)$ was determined using the following formula:

$$
\mu=\frac{\operatorname{Ln} N_{1}-\operatorname{Ln} N_{2}}{t_{1}-t_{2}}
$$

Where, $\mathrm{N}_{1}$ and $\mathrm{N}_{2}$ represent the chl- $a$ concentrations at times $t_{1}$ and $t_{2}$, respectively, within the whole experiment period. The cells were harvested at the end of the experiment by filtration for dry weight determination $\left(100^{\circ} \mathrm{C}\right.$, 24h) and extraction of lipids.

Lipid extraction and fatty acid analysis

Lipids were extracted in methanol-chloroformwater $(2: 1: 0.8)$ before being determined by the gravimetric method [46]. The lipids were transesterified in $1 \% \mathrm{H}_{2} \mathrm{SO}_{4}$ in methanol and the fatty acid methyl esters were analysed by gas chromatography [47].

\section{Statistical analysis}

One-way analysis of variance (ANOVA) was used to determined whether there was any significant difference between the treatments used at $\mathrm{P}>0.05$ followed by comparison of means using Newman-Keuls Multiple Range test. All statistical analyses were performed using the statistical software Statistical Version 6.0.

\section{RESULTS}

The intensities of UVA radiation, UVB radiation and PAR from $25^{\text {th }}$ to $27^{\text {th }}$ January 2006 recorded in the roof-top (natural) UVR study ranged from 3.66 to $27.95 \mathrm{Wm}^{-2}, 1.61$ to $16.50 \mathrm{Wm}^{-2}$ and 282 to $1480 \mu \mathrm{mol} \mathrm{m} \mathrm{s}^{-2}$, respectively (Figure 2). The water temperature during the roof-top (natural) UVR experiment was difficult to control and the temperatures ranged from 26.6 to $39.6^{\circ} \mathrm{C}$. On the other hand, the air temperature ranged from 31.8 to $41.5^{\circ} \mathrm{C}$ (Figure 3).

\section{UVR intensities and PAR irradiance}

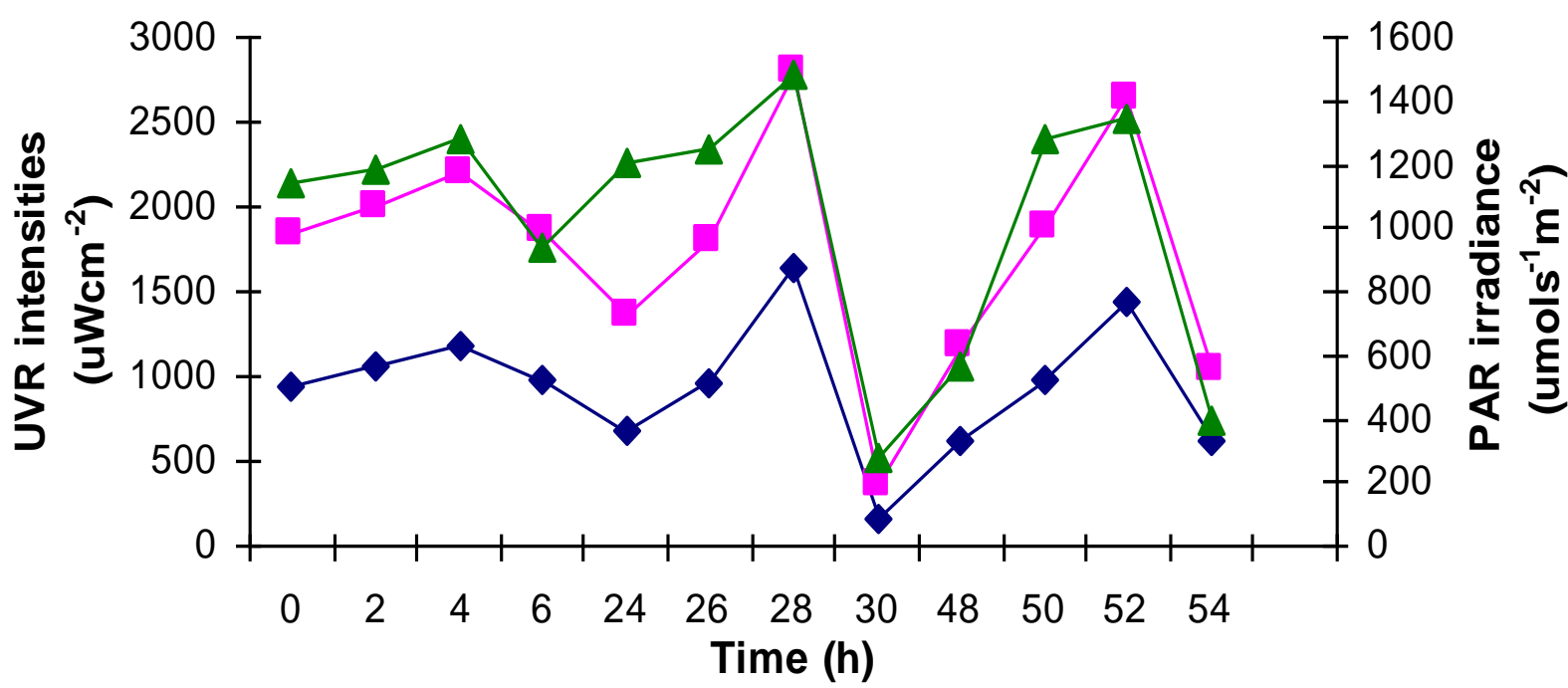

Figure 2: UVR and PAR irradiance measured during the roof-top (natural UVR) study at Institute of Graduate Studies Building, University of Malaya . UVB radiation; $\bullet$ UVA radiation; $\triangle$ PAR 


\section{Temperature}

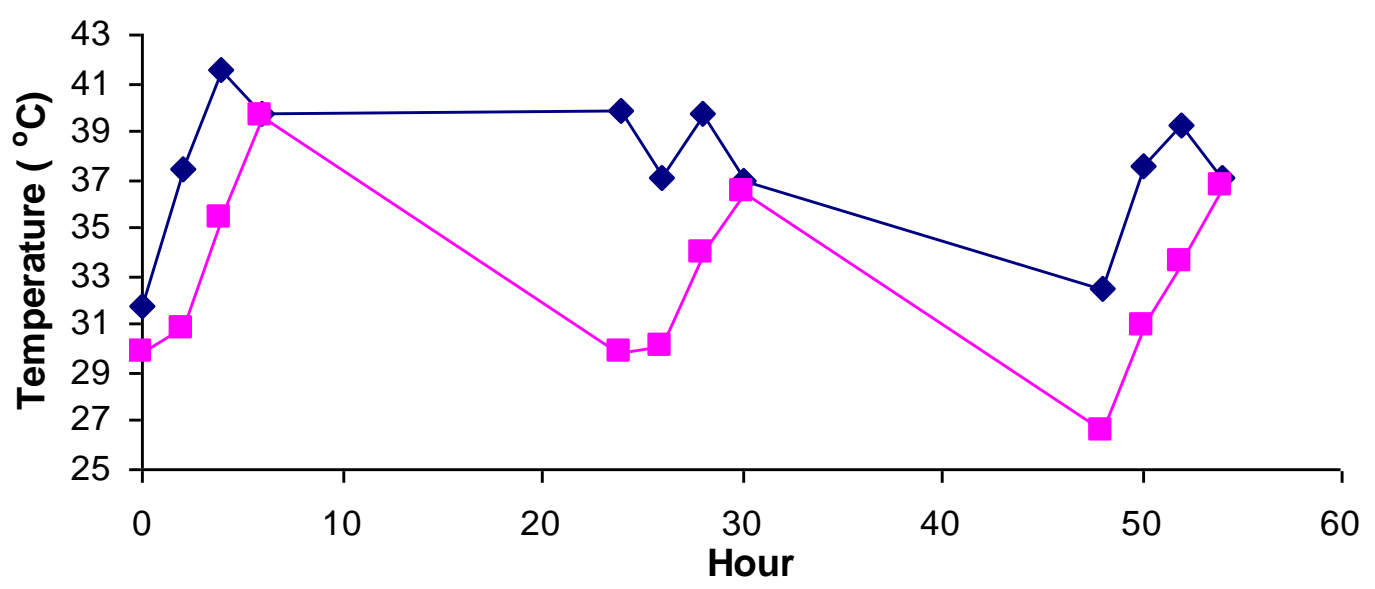

Figure 3 : Variations of temperature during the roof top (natural UVR) study at Institute of Graduate Studies Building, University of Malaya. air temperature; water temperature

Similar growth trends were observed in Chorella vulgaris UMACC 001 subjected to PAR+UVA and PAR alone in the laboratory study as shown in Figure 4. The $\mu$ value for Chlorella vulgaris UMACC 001 exposed to PAR+UVA did not differ significantly ( $P>0.05)$ compared to PAR alone. In contrast, the cultures exposed to PAR+UVA+UVB did not grow well compared to PAR alone as indicated by their lower $\mu$ value compared to PAR alone $(\mathrm{P}<0.05)$ (Figure 5). Similarly, the final chlorophyll $a$ concentration at day 10 of the culture exposed to PAR+UVA+UVB $\left(0.31 \mathrm{mgL}^{-1}\right)$ was very low compared to the culture exposed to PAR alone (1.19 $\left.\mathrm{mgL}^{-1}\right)$. However, there was no significant difference in the chlorophyll $a$ concentration for the cultures subjected to different UVR treatments at day 2 $(\mathrm{P}>0.05)$. Similar result for chlorophyll $a$ concentration was observed in the cultures exposed to the natural UVR at day 2. In addition, there was no significant difference in the $\mu$ values of the cultures exposed to PAR+UVA+UVB, PAR+UVA and PAR alone in the natural environment $(\mathrm{P}>0.05)$.

Lipid content decreased in cells exposed to PAR+UVA compared to PAR alone while there was no significant difference in cells exposed to $\mathrm{PAR}+\mathrm{UVA}+\mathrm{UVB}$ compared to PAR alone in the laboratory study (Figure 6). On the other hand, the lipid content decreased in cells exposed to PAR+UVA+UVB compared to PAR alone in the roof-top (natural UVR) study. However, the effect of UVB radiation was not significant compared to PAR alone. There was also no significant difference $(\mathrm{P}>0.05)$ in lipid content for the cultures exposed to
PAR+UVA and PAR alone in the natural environment.

Fatty acid profiles of Chlorella vulgaris UMACC 001 in the laboratory and roof-top (natural UVR) studies are shown in Table 1. Saturated Fatty Acids (SFA) were dominant in the control in both laboratory and roof-top (natural UVR) studies. However, its content decreased when the cultures were exposed to PAR+UVA and increased under PAR+UVA+UVB exposure in laboratory condition. The reverse trend was found in the content of polyunsaturated fatty acids (PUFA). Different response was observed for the cultures exposed to natural UVR in the roof-top study. The content of SFA was slightly lower in the cultures exposed to PAR+UVA and PAR+UVA+UVB compared to PAR alone. In contrast, the contents of MUFA and PUFA were significantly increased $(\mathrm{P}<0.05)$ when the cultures were exposed to natural PAR+UVA and $\mathrm{PAR}+\mathrm{UVA}+\mathrm{UVB}$ compared to PAR alone.

\section{DISCUSSION}

The levels of UVR decrease with increasing latitude, being highest in the tropics and lowest in the polar region [48]. It is because of the high solar angle and a relatively low amount of stratospheric ozone near the equator $[48,49]$. The intensities of UVA radiation, UVB radiation and PAR irradiance measured during the roof-top (natural UVR) study in January 2006 were 3.66 to $27.95 \mathrm{Wm}^{-2}, 1.61$ to 16.50 $\mathrm{Wm}^{-2}$ and 282 to $1480 \mu \mathrm{mol} \mathrm{m}^{-2} \mathrm{~s}^{-1}$, respectively. The measurements conducted across Argentina showed 

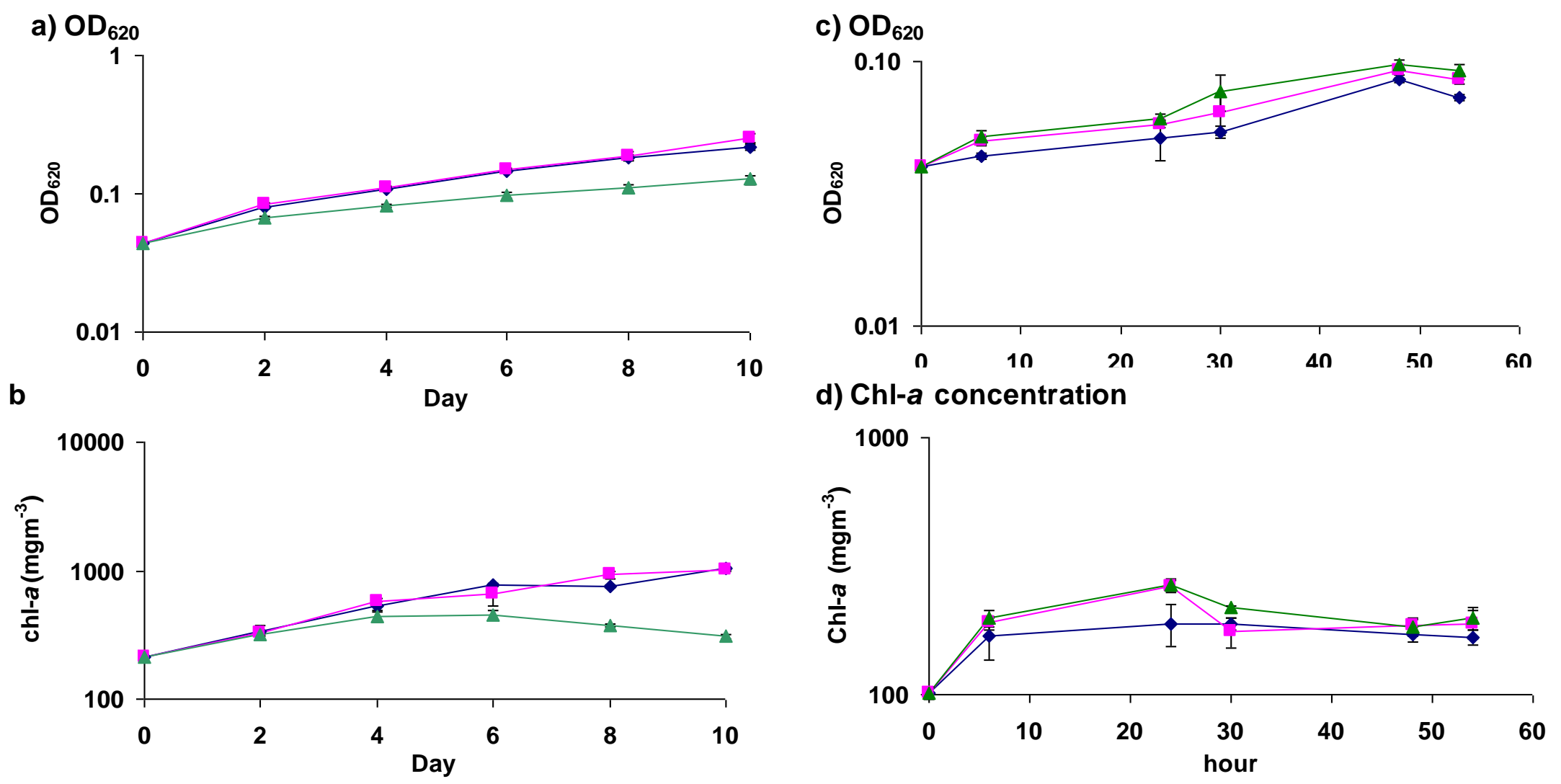

Figure 4: Semi-logarithmic growth curves based on chl- $a$ concentration of Chlorella vulgaris UMACC 001 exposed to UVR and PAR alone under laboratory (a, b) and roof-top (natural UVR) (c, d) conditions. Vertical bars denote standard deviations from triplicate samples. PAR alone; I PAR+UVA; $A$ $\mathrm{PAR}+\mathrm{UVA}+\mathrm{UVB}$ 


\section{a) Specific growth rate}

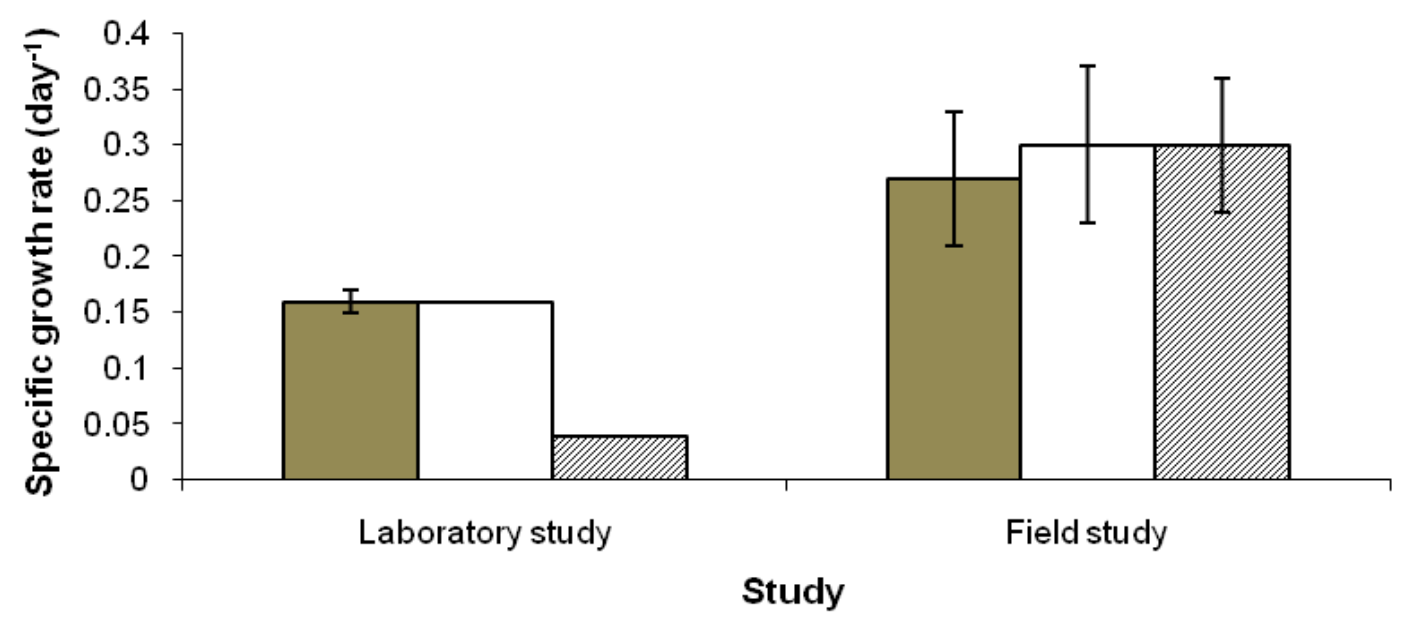

\section{b) Chl-a concentration}

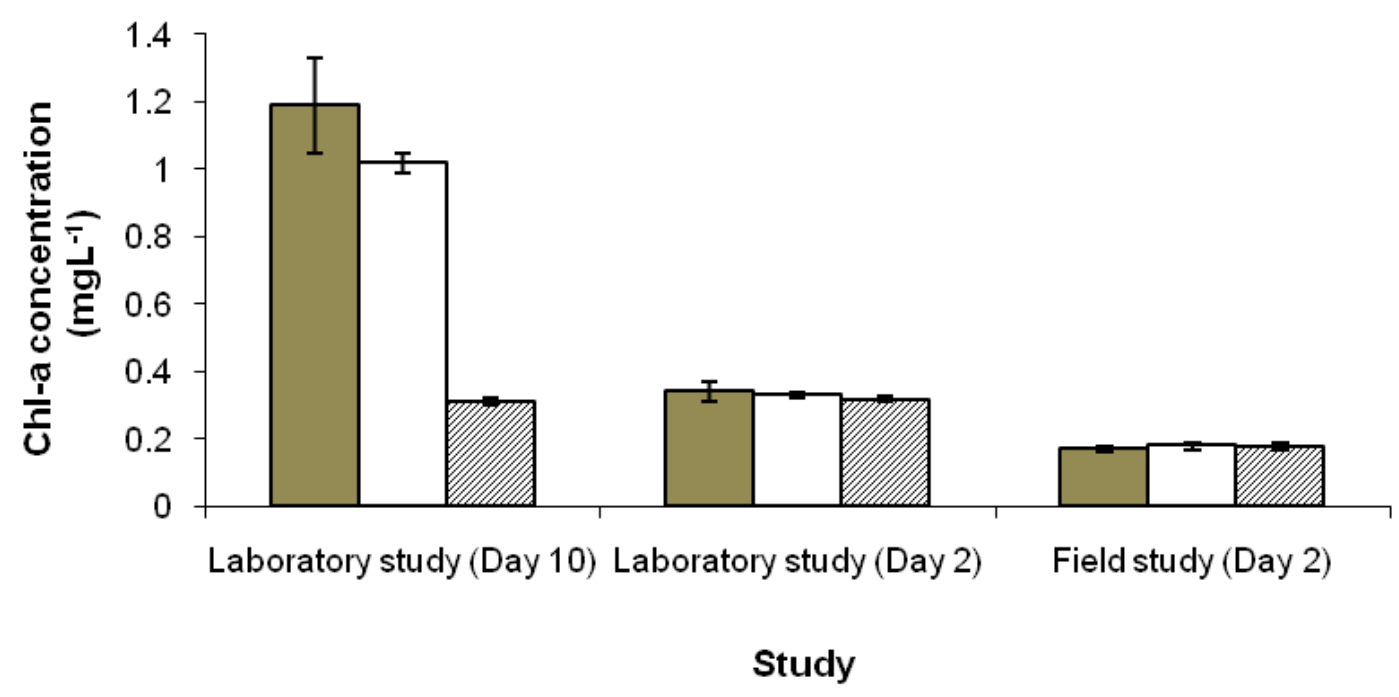

Figure 5: Specific growth rates (a) and chl-a concentration (b) of Chlorella vulgaris UMACC 001 exposed to UVR and PAR alone under laboratory and roof-top (natural UVR) conditions. Vertical bars denote standard deviations from triplicate samples. $\square$ PAR alone;

$\square$ PAR+UVA;

that the noontime levels of UVB radiation decreased from $4.46 \mathrm{Wm}^{-2}$ at Jujuy (tropics) to $3.99 \mathrm{Wm}^{-2}$ at Buenos Aires (temperate) and to $2.61 \mathrm{Wm}^{-2}$ at Ushuaia (sub-Antarctic) [50]. Whereas under clear skies at temperate to equatorial latitudes, total UVB radiation maybe as high as 7 to $8 \mathrm{Wm}^{-2}$ and UVA radiation as high as 45 to $50 \mathrm{Wm}^{-2}$, respectively [25]. On the other hand, the water temperature during the field experiment was difficult to control and there was great fluctuation in air temperature. This was due to the unstable weather during the field experiment.

Chlorella vulgaris UMACC 001 showed similar response to UVA radiation under both laboratory and roof-top (natural UVR) studies. The present study 
Table 1: Fatty acid profiles of Chlorella vulgaris UMACC 001 exposed to UVR and PAR alone in laboratory and roof-top (natural UVR) condition.

\begin{tabular}{|c|c|c|c|c|c|c|}
\hline \multirow{2}{*}{$\begin{array}{l}\text { Fatty } \\
\text { acid }\end{array}$} & \multicolumn{3}{|c|}{ Laboratory study } & \multicolumn{3}{|c|}{ Field study } \\
\hline & PAR & PAR+UVA & $\mathrm{PAR}+\mathrm{UVA}+\mathrm{UVB}$ & PAR & $\mathrm{PAR}+\mathrm{UVA}$ & PAR+ \\
\hline \multicolumn{7}{|c|}{ Saturated fatty acids } \\
\hline 14:0 & 2.0 & 2.0 & 3.2 & 4.4 & 5.4 & 4.3 \\
\hline $16: 0$ & 27.3 & 26.0 & 33.0 & 28.9 & 26.7 & 27.4 \\
\hline 18:0 & 25.5 & 18.4 & 25.8 & 45.9 & 29.9 & 31.3 \\
\hline Total & 54.8 & 46.4 & 62.0 & 79.2 & 62.0 & 63.0 \\
\hline
\end{tabular}

Monounsaturated fatty acids

$\begin{array}{ccccccc}16: 1 & 5.3 & 5.8 & 3.7 & 2.3 & 3.4 & 3.9 \\ 18: 1 & 2.6 & 2.9 & 4.9 & 1.0 & 3.3 & 2.6 \\ \text { Total } & 7.9 & 8.7 & 8.6 & 3.3 & 6.7 & 6.5\end{array}$

Polyunsaturated fatty acids

\begin{tabular}{lllllll}
$16: 2$ & 3.4 & 4.3 & 1.1 & 0.3 & 1.1 & 1.8 \\
$16: 3$ & 8.0 & 9.3 & 6.8 & 3.8 & 7.0 & 6.6 \\
$18: 2$ & 8.4 & 10.6 & 5.0 & 4.8 & 7.8 & 7.4 \\
$18: 3$ & 17.5 & 20.7 & 16.5 & 8.6 & 15.3 & 14.7 \\
Total & 37.3 & 44.9 & 29.4 & 17.5 & 31.3 & 30.5 \\
\hline \hline
\end{tabular}

Data as mean, percentage of total fatty acids, $n=3$

showed that there was no negative effect of UVA radiation on growth. Positive effects of UVA radiation have been extensively reported. For example, Wong et al $[10,11]$ reported that there was no adverse effect of UVA radiation on the growth of Antarctic, tropical and temperate microalgae. UVA radiation has been proved to favor photosynthesis in some selected phytoplankton [34, 35]. In addition, the presence of UVA radiation has resulted in higher biomass production in Arthrospira platensis compared to those grown under PAR alone [53]. 


\section{Lipid content}

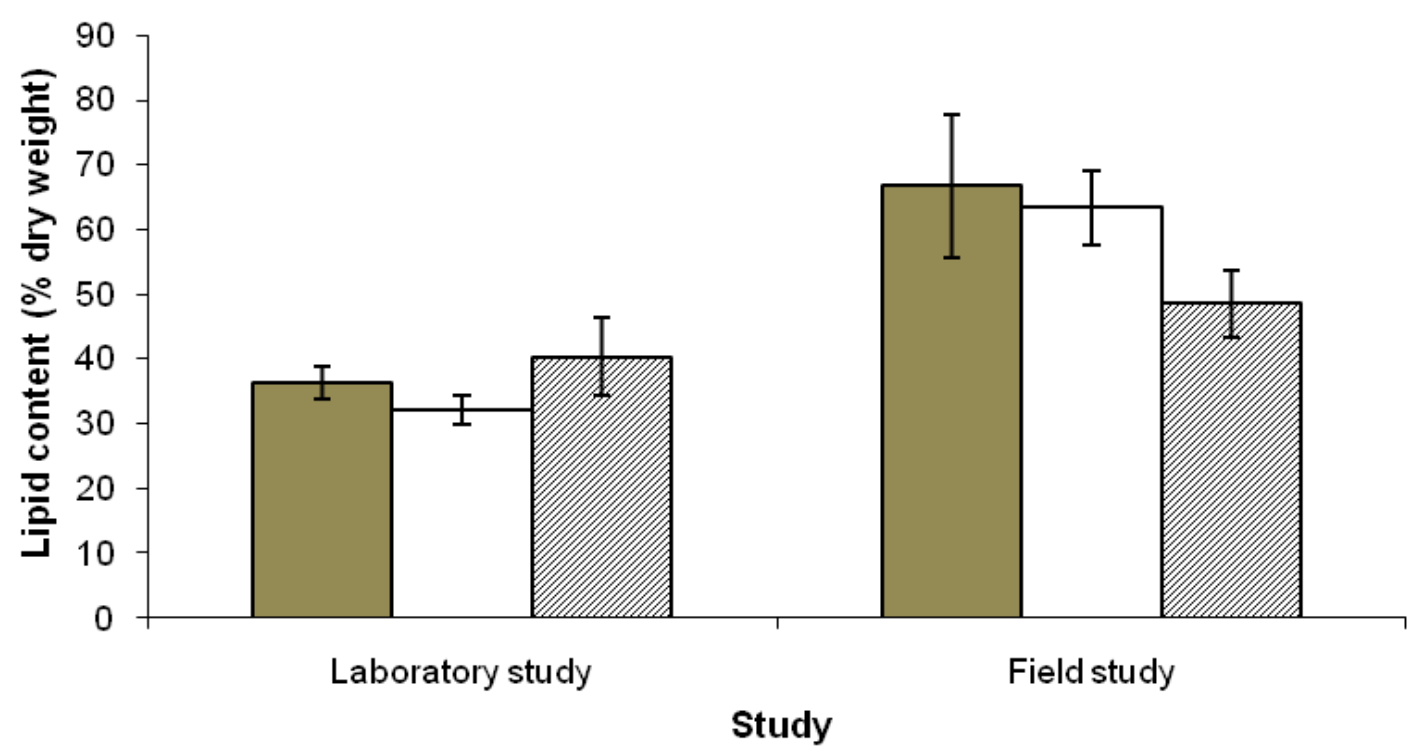

Figure 6: Lipid content (\% dry weight) of Chlorella vulgaris UMACC 001 exposed to UVR and PAR alone in laboratory and roof-top (natural UVR) condition. Vertical bars denote standard deviations from triplicate samples. $\square$ PAR alone; $\square$ PAR+UVA; $\square$ PAR+UVA+UVB

showed that there was no negative effect of UVA radiation on growth. Positive effects of UVA radiation have been extensively reported. For example, Wong et al $[10,11]$ reported that there was no adverse effect of UVA radiation on the growth of Antarctic, tropical and temperate microalgae. UVA radiation has been proved to favor photosynthesis in some selected phytoplankton [34, 35]. In addition, the presence of UVA radiation has resulted in higher biomass production in Arthrospira platensis compared to those grown under PAR alone [53].

On the other hand, the growth of Chlorella vulgaris UMACC 001 was adversely affected by UVB radiation in the laboratory study as shown by the significant decrease of $\mu$ value and final chlorophyll $a$ concentration at day 10 compared to PAR alone. However, there was no adverse effect of UVB radiation in the roof-top (natural UVR) study. It could be explained that the duration of the experiment (two days) was too short for UVB radiation to impose significant effect on the growth of this microalga, as there was also no significant effect of UVB radiation on chlorophyll $a$ concentration at day 2 in the laboratory study. However, a reduction of chlorophyll $a$ was observed in Chlorella fusca after being exposed to UVB fluences of $1230 \mathrm{Jm}^{-1} \mathrm{day}^{-1}$ for $5 \mathrm{~h} /$ day for 2 days [54]. The difference in response compared to the present study could be due the different UVB radiation intensity used.

The adverse effect of UVB radiation on growth has been reported in Antarctic Chlorella UMACC 237 and temperate Chlorella vulgaris UMACC 248 [10,11]. In addition, Malanga and Puntarulo [55] also reported that growth expressed as chlorophyll content, declined significantly with increased UVB dose in Chlorella vulgaris. The reduction in the concentration of chlorophyll $a$, which functions as a photosynthetic pigment observed after 10 days of UVB radiation exposure suggest that UVB radiation may reduce the photosynthetic capacity of this microalga. According to Buma et al [56] and Estevez et al [14], the adverse effect of UVB could be due to its influence on photosynthesis and the generation of oxygen radicals which may damage molecules such as proteins and DNA.

The present study showed that there was no significant effect of UVB radiation on lipid content in Chlorella vulgaris UMACC 001 in both laboratory and roof-top (natural UVR) studies although the reduction of lipid content was observed in the cultures exposed to UVB radiation in roof-top (natural UVR) study. An increase in lipid content has been reported in Antarctic Chlorella UMACC 237 after exposure to UVB radiation compared to PAR 
alone [10]. However, decrease in lipid content has been observed in Antarctic microalgae such as Klebsormidium UMACC 227 and Navicula UMACC 231 exposed to $5.15 \mathrm{Wm}^{-2}$ of UVB radiation [10] and Odontella weissflogii [57]. The decrease of lipid content under UVB exposure may indicate the degradation of complex lipid. The different response of this tropical Chlorella vulgaris UMACC 001 in the present study compared to other studies suggest that Chlorella vulgaris UMACC 001 might be using different adaptive mechanisms involving molecules other than lipids to cope with the UVB stress.

Chlorella vulgaris UMACC 001 exhibited different response in terms of fatty acid profiles when exposed UVB radiation in the laboratory and roof-top (natural UVR) studies. There was an increase in the SFA at the expense of PUFA when the microalga was exposed to UVB radiation in the laboratory study and it was in agreement with most of the past studies. For example, the percentage of PUFA in Antarctic Chlorella [10] and Chaetoceros simplex [57] decreased while SFA increased significantly when exposed to a high intensity of UVB radiation. SFA has been reported to serve as energy source for stress adaptation while PUFAs are vital constituents of the cell wall and are essential for chlorophyll membrane development as well as important dietary function in the food web [58,59]. Decrease in the proportion of PUFA within the cell wall membranes of phytoplankton can reduce membrane permeability and therefore weaken the ability of phytoplankton to assimilate nutrients important for growth $[60,61]$.

On the other hand, a reverse trend of fatty acid profile was found when the Chlorella vulgaris UMACC 001 was exposed to natural UVB radiation in roof-top (natural UVR) study where there was a significant increase in PUFA at the expense of SFA. The response of this microalga to UVB radiation in the roof-top (natural UVR) study suggested that biosynthesis of PUFA might be enhanced and SFA formation was suppressed when exposed to solar UVB radiation for two days. This agrees with the findings of Liang et al [28] who showed that the exposure of UVR radiation for two days resulted in an increase of PUFA at the expense of SFA in both Phaeodactylum tricornutum and Chaetoceros muelleri. The difference observed in fatty acid profiles of Chlorella vulgaris UMACC 001 in the laboratory and roof-top (natural UVR) studies could be related to the different UVR exposure time because the laboratory was studied for ten days while the roof-top (natural UVR) study lasted only two days. The increases of MUFA and PUFA in the twodays roof-top (natural UVR) study indicate that these fatty acids might serve as an immediate adaptive mechanism to short-term UVB exposure.

In conclusion, laboratory-produced UVA and natural UVA radiation (roof-top) has no effect on the growth of Chlorella vulgaris UMACC 001 based on chl- $a$ concentration. In contrast, the growth of this microalga was adversely affected by UVB radiation exposure for 10 days under laboratory culture condition. The biochemical properties especially the fatty acid profiles of the microalga changed from laboratory culture to roof-top (natural UVR) culture condition. The response of Chlorella vulgaris UMACC 001 to UVR was dependent on culture location (laboratory, roof-top) and duration of UVR exposure. As microalgae form the basis in many food-webs, any change in fatty acid composition may affect the nutritional value of the microalgae for organisms at higher trophic levels in the ecosystem.

\section{ACKNOWLEDGEMENTS}

The grants (\#8123203) from the Ministry of Science, Technology and Innovation (MOSTI), Malaysia coordinated by the Academy of Sciences Malaysia (ASM) and Short Term Research grant (P0158/2006A) from University of Malaya, which supported this research are gratefully acknowledged.

\section{REFERENCES}

1. Stolarski R., Bojkov R., Bishop L., Zerefos C., Staehelin J. and Zawodny J. (1992). Measured trends in stratospheric zone. Science, 256:342-349.

2. World Meteorological Organization, WMO (1995). Scientific Assessment of Ozone Depletion, In: Global Ozone Research and Monitoring Project, Report No. 37. (eds. Albritton D. and Watson R.).

3. Tabazadeh A., Santee M.L., Danilin M.Y., Pumphrey H.C., Newman P.A., Hamill P.J. and Mergenthaler J.L. (2000). Quantifying denitrification and its effect on ozone recovery. Science, 288:1407-1411.

4. Salawitch R.J. (1998). A greenhouse warming connection. Nature, 392:551-552.

5. Shindell D.T., Rind D. and Lonergan P. (1998) Increased polar stratospheric ozone losses and delayed eventual recovery owing to increased greenhouse-gas concentrations. Nature, 392:589-592.

6. Houghton J.T., Ding Y., Griggs D.J., Noguer M., Van der Linden P.J., Dai X., Maskell L. and Johnson C.A. (2001). Climate change 2001: the scientific basis. 
Cambridge University Press, Cambridge. p.p.881.

7. Roscoe H.K., Jones A.E. and Lee A.M. (1997). Midwinter start to Antarctic ozone depletion: evidence from observations and model. Science, 278:93-96.

8. Hughes K.A. (2006). Solar UV-B radiation, associated with ozone depletion, inhibits the Antarctic terrestrial microalgae, Stichococcus bacillaris. Polar Biology, 29:327-336.

9. Hader D.-P. (2006). Impact of UV radiation on the aquatic environment In: Environmental UV radiation: Impact on ecosystem and Human health and Predictive Models, (eds F. Ghetti et al). Netherlands, pp.179-191.

10. Wong C.Y., Chu W.L., Marchant H. and Phang S.M. (2004). Growth response, biochemical composition and fatty acid profiles of four Antarctic microalgae subjected to UV radiation stress. Malaysian Journal of Science, 23(2):103-118.

11. Wong C.Y., Chu W.L., Marchant H. and Phang S.M. (2007). Comparing the response of Antarctic, tropical and temperate microalgae to ultraviolet (UVR) stress Journal of Applied Phycology, 19:689-699.

12. Helbling E.W., Villafane V.E., Buma A.G.J., Andrade M. and Zaratti F. (2001). DNA damage and photosynthetic inhibition induced by solar ultraviolet radiation in tropical phytoplankton (Lake Titicaca, Bolivia). European Journal of Phycology, 36:157-166.

13. Shelly K., Simon S., Heraud P. and Beardall J. (2005). Interactions between UVB exposure and phosphorus nutrition. I. Effects on growth, phosphate uptake, and chlorophyll fluorescence. Journal of Phycology, 41, 1204-1211.

14. Estevez M.S., Malanga G. and Puntarulo S. (2001). UV-B effects on Antarctic Chlorella cells. Journal of Photochemistry and Photobiology B, 62: 19 - 25 .

15. Asada K. and Takahashi M. (1987). Production and scavenging of active oxygen in photosynthesis. In Kyle D.J., Osmond C.B. and Arntzen C.J. (eds) Photoinhibition. Elsevier, Amsterdam, pp. 227-287.

16. Wang K.S. and Chai T. (1994). Reduction in omega-3 fatty acids by UV-B irradiation in microalgae. Journal of Applied Phycology, $6,415-421$.

17. Gao K., Guan W. and Helbling E.W. (2007). Effects of solar ultraviolet radiation on photosynthesis of the marine red tide alga Heterosigma akashiwo (Raphidophyceae). Journal of Photochemistry and Photobiology B: Biology, 86, 140-148.

18. Tian J. and Yu J. (2009). Changes in ultrastructure and responses of antioxidant systems of algae (Dunaliella salina) during acclimation to enhanced ultraviolet $-\mathrm{B}$ radiation. Journal of Photochemistry and Photobiology B:Biology, 97, 152-160

19. Babu T.S., Jansen M.A.K., Greenberg B.M., Gaba V., Malkin S., Mattoo A.K. and Edelman M. (1999). Amplified degradation of photosystem II D1 and D2 proteins under a mixture of photosynthetically active radiation and UVB radiation: dependence on redox status of photosystem II. Photochemistry and Photobiology, 69, 553559.

20. Booij-James I.S., Dube S.K., Jansen M.A.K., Edelman M. and Mattoo A.K. (2000). Ultraviolet-B radiation impacts light-mediated turnover of the photosystem II reaction center heterodimer in Arabidops is mutants altered in phenolic metabolism. Plant Physiology, 124, 1275-1283.

21. Jordan B.R. (1996). The effects of ultraviolet $B$ radiation on plants: a molecular perspective. Advances in Botanical Research, 22, 97-162.

22. Baroli I. and Melis A. (1996). Photoinhibition and repair in Dunaliella salina acclimated to different growth irradainces. Planta, 198, 640-646.

23. Bouchard J.N., Campbell D.A. and Roy S. (2005). Effects of ultraviolet-B radiation on the D1 protein repair cycle of natural phytoplankton communities from the three latitudes (Canada, Brazil, Argentina). Journal of Phycology, DOI 10.1111/j-15298817.2005.04126.x

24. Neale P.J., Cullen J.J., Lesser M.P. and Melis A. (1993). Physiological bases for detecting and predicting photoinhibition of aquatic photosynthesis by PAR and UV radiation. In Yamamoto, H.Y. \& Smith, C.M. (eds) Photosynthetic Responses to the Environment. American Society of Plant Physiologist, Rockville. Maryland, pp. 6177.

25. Holzinger A. and Lutz C. (2006). Algae and UV irradiation: Effects on ultrastructure and related metabolic functions. Micron, 37:190207.

26. Sundback K., Odmark S., Wulff A., Nilsson C. and Wangberg S.A. (1997). Effects of 
enhanced UVB radiation on a marine benthic diatom mat. Marine Biology, 128, 171-179.

27. Liang Y., Beardall J. and Heraud P. (2006a). Effects UV radiation on growth, chlorophyll fluorescence and fatty acid composition of Phaeodactylum tricornutum and Chaetoceros muelleri (Bacillariophyceae). Phycologia, 45, 605-615.

28. Liang Y., Beardall J. and Heraud P. (2006b). Effects of nitrogen source and UV radiation on the growth, chlorophyll fluorescence and fatty acid composition of Phaeodactylum tricornutum and Chaetoceros muelleri (Bacillariophyceae). Journal of Photochemistry and Photobiology B: Biology, 82:161-172.

29. Nilawati J., Greenberg B.M. and Smith R.E.H. (1997). Influence of ultraviolet radiation on growth and photosynthesis of two cold ocean diatom. Journal of Phycology, 33, 215-224.

30. Hermann H., Hader D.-P. and Ghetti F. (1997). Inhibition of photosynthesis by solar radiation in Dunaliella salina: relative efficiencies of UVB, UVA \& PAR. Plant, Cell and Environment, 20, 359-365.

31. Lutz C., Seidlitz, H.K. and Meindl, H.K.U. (1997). Physiological and structural changes in the chloroplast of the green alga Micrasterias denticulata induced by UV-B simulation. Plant Ecology, 128, 55-64.

32. Mackerness S.A.H., Jordan B.R. and Thomas B. (1999). Reactive oxygen species in the regulation of photosynthetic genes by ultraviolet-B radiation (UV-B:280-320nm) in green and etiolated buds of pea (Pisum sativum L.). Journal of Photochemistry and Photobiology, 48, 180-188.

33. Rijstenbil J.W. (2001). Effects of periodic, low UVA radiation on cell characteristics and oxidative stress in the marine planktonic diatom Ditylum brightwellii. European Journal Phycology, 36:1-8.

34. Shiu C.T. and Lee T.M. (2005). Ultraviolet$\mathrm{B}$-induced oxidative stress and responses of the ascorbate-glutathione cycle in a marine macroalgae Ulva fasciata. Journal of Experimental Botany, 56(421):2851-2865.

35. Gojo R., Suzuki H. and Tezuka T. (2004). Regulation of ethylene-forming system in Chlorella by near-UV radiation. Environmental Science 11(4):199-208.

36. Villafane V.E., Marcoval M.A. and Helbling E.W. (2004). Photosynthesis versus irradiance characteristics in phytoplankton assemblages off Patagonia (Argentina): temporal variability and solar UVR effects. Marine Ecology Progress Series, 284: 23 34.

37. Vimalabai C.P.M. and Kulandaivelu G. (2002). Effects of prolonged UV-B enhanced fluorescent radiation on some marine microalgae. Biologia Plantarum, 45(3):389-394.

38. Gors M., Schumann R., Hepperle D. and Karsten U. (2010). Quality analysis of commercial Chlorella products used as dietary supplement in human nutrition. Journal of Applied Phycology, 22:265-276.

39. Hajimahmoodi M., Faramarzi M.A., Mohammadi N., Soltani N., Oveisi M.R. and Nafissi-Varcheh N. (2010). Evaluation of antioxidant properties and total phenolic contents of some strains of microalgae. Journal of Applied Phycology, 22:43-50.

40. Chu W.L., See Y.C. and Phang S.M. (2009). Use of immobilized Chlorella vulgaris for the removal of colour from textile dyes. Journal of Applied Phycology, 21:64-648.

41. Xu H., Mia X. and Wu Q. (2006). High quality biodiesel production from a microalgae Chlorella protothecoides by heterotrophic growth in fermenters. Journal of Biotechnology, 126:499-507.

42. Phang S.M. and Chu W.L. (1999). University of Malaya Algae Culture Collection (UMACC): catalogue of strains. Institute of Postgraduate Studies and Research, University of Malaya, pp. 77

43. Nichols HW (1973). Growth media freshwater. In: Handbook of phycological methods: culture methods and growth measurements. (ed. Stein J.) Cambridge University Press, Cambridge, pp. 7-24

44. Thimijan R.W. and Royal D.H. (1983). Photometric, radiometric, and quantum light units of measure: A review of procedures for interconversion. Horticultural Science, 18:818-822.

45. Strickland J.D.H. and Parsons T.R. (1968). A Practical Handbook of Seawater Analysis. Bull No 167, Fisheries Res Bd Can, pp. 310.

46. Bligh E.G. and Dyer W.J. (1959). A rapid method of total lipid extraction and purification. Canadian Journal of Biochemistry and Physiology, 37: 911-917.

47. Chu W.L., Phang S.M. and Goh S.H. (1994). Studies on the production of useful chemicals, especially fatty acids in the marine diatom Nitzschia conspicua Grunow. Hydrobiologia, 285:22-40. 
48. Madronich S., McKenzie R.L., Caldwell M.M. and Bjorn L.O. (1995). Changes in ultraviolet radiation reaching the Earth's surface. Ambio, 24:143-152.

49. Madronich, S. (1994). Increases in biologically damaging UV-B radiation due to stratospheric ozone reductions. Ergebn Limnol., 43:17-30.

50. Orce V.L. and Helbling E.W. (1997). Latitudinal UVR-PAR measurements in Argentina: extent of the "ozone hole". Global and Planetary change. 15:113-121.

53

54. Wu H., Gao K., Villafane V.E., Watanabe T. and Helbling E.W. (2005). Effects of solar UV radiation on morphology and photosynthesis of filamentous cyanobacterium Arthrospira platensis. Applied and Environmenatal Microbiology, 71(9):5004-5013.

55. Dohler G. (1989). Impact of UV-B radiation on nitrogen metabolism of marine phytoplankton. In Plants and pollutants in developed and developing countries. (ed. Ozturk M.A.) E.U. Press. Turkey. pp. 57-87.

56. Malanga G. and Puntarulo S. (1995). Oxidative stress and antioxidant content in Chlorella vulgaris after exposure to ultraviolet-B radiation. Physiologia Plantarum, 94:672-679.

57. Buma A.G.J., Wright S.W., Van den Enden R., Van de Poll W.H., Davidson A. (2006). PAR acclimation and UVBR-induced DNA damage in Antarctic marine microalgae. Marine Ecology Progress Series, 315: $33-$ 47.

58. Skerratt J.H., Davidson A.D., Nichols P.D. and Mc Meekin T.A. (1998). Effect of UVB on lipid content of three Antarctic marine phytoplankton. Phytochemistry, 49:999. 1007.

59. Roessler P.G. (1990). Environmental control of glycerolipid metabolism in microalgae: commercial implications and future research directions. Journal of Phycology, 26:393399.

60. Thompson P.J., Harrison P.J. and Whyte J.N.C. (1990). Influence of irradiance on the fatty acid composition of phytoplankton. Journal of Phycology, 26:278-288.

61. Claustre H., Marty J. and Cassiani L. (1989). Intraspecific differences in the biochemical composition of a diatom during a spring bloom in Villefrabche-sur-Mer Bay, Mediterranean Sea. Journal of Experimental Marine Biology and Ecology, 129:17-32.
51. Barbieri E.S., Villafane V.E. and Helbling E. W. (2002). Experimental assessment of UV effects upon temeperate marine phytoplankton when exposed to variable radiation regimes. Limnology and Oceanography, 47:1648-1655.

52. Helbling E.W., Gao K., Goncalves R.J., Wu H. and Villafane V.E. (2003). Utilization of solar ultraviolet radiation by phytoplankton assemblages from the Southern China Sea when exposed to fast mixing condition. Marine Ecology Progress Series, 259:59-66.

62. Goes J.I., Handa N., Taguchi S. and Hama T. (1994). Effect of UV-B radiation on the fatty acid composition of the marine phytoplankton Tetraselmis sp.: relationship to cellular pigments. Marine Ecology Progress Series, 114:259-274. 